\title{
Ovarian Germ Cell Tumor - Histopathological and statistical analysis
}

\author{
Ghosh A ${ }^{1}$, Gharti Magar D ${ }^{1}$, Sathian B ${ }^{2}$, Narasimhan R ${ }^{1}$, Talwar Op ${ }^{1}$ \\ ${ }^{I}$ Department of Pathology, Manipal College of Medical Sciences, Pokhara, Nepal \\ ${ }^{2}$ Department of Community Medicine, Manipal College of Medical Sciences, Pokhara, Nepal
}

\section{Keywords: \\ Germ cell tumor; Ovarian tumor; Ovary; \\ Teratoma}

\begin{abstract}
Background: Ovarian cancers are common among females. The ovarian tumors are classified according to its histogenesis. In the present study, we analyzed the germ cell ovarian tumors reported in our institute.

Materials and Methods: This study was a hospital based retrospective study. All ovarian germ cell tumor reported from Jan 2001 to Feb 2013 were retrieved and analyzed. The specimens were routinely processed and the slides were stained with $H \& E$ and special stains wherever required.

Results: A total of 340 cases of ovarian tumors were reported and 150 cases (44\%) were of germ cell origin. We had 137 cases of benign and 13 cases of malignant germ cell tumors. Most common subtype was mature cystic teratoma comprising 125 cases. Among the malignant cases, the most common was immature teratoma ( 5 cases). Age range in our series was from 8 to 82 years (mean 28 years). The most common age group affected was 21-30 years. Most of the malignant cases (76.9\%) were in less than 30 years. Among the malignant cases majority $(84.6 \%)$ were more than $10 \mathrm{~cm}$ in size. None of the malignant germ cell tumors were bilateral.
\end{abstract}

Conclusion: Among germ cell tumors of ovary, mature cystic teratoma is the most common tumor and malignant subtypes are uncommon. Malignant tumors tend to occur in younger age group.

\section{INTRODUCTION}

Ovarian cancers are common among females comprising $30 \%$ of cancers of female genital tracts and $6 \%$ of all cancers in females. ${ }^{1,2}$. It is the most common cause of death due to cancer of female genital tract and the fifth leading cause of cancer related deaths in females. ${ }^{3}$ It is least in the developing countries of South East Asia and Africa and highest in the industrialized developed countries of Europe and North America. ${ }^{1,4}$. In the present study, we analyze the germ cell ovarian tumors reported in our institute.

\section{Correspondence:}

Dr Arnab Ghosh, MD Associate Professor,

Department of Pathology Manipal Teaching Hospital, Manipal College of Medical Sciences, Pokhara, Nepal

Email:drghosharnab@yahoo.com

\section{MATERIALS AND METHODS}

\section{Design}

This study was a hospital based retrospective study carried out in the department of pathology, Manipal Teaching Hospital. All the ovarian tumors of germ cell origin reported in the department over a time period from January 2001 to February 2013 were retrieved and the data were analyzed. The tissues were routinely fixed with $10 \%$ formalin and the slides were stained with Hematoxylin and Eosin (HE) stains and also with special stains wherever required.

\section{Outcome Variable}

Main outcome variable was germ cell tumor. Others were 
all the subtypes including benign and malignant tumors.

\section{Explanatory Variable}

Age (<10, 11-20, 21-30, 31-40, 41-50, 51-60, 61-70, >70) Side (uni-, bilateral), Size (upto $5 \mathrm{~cm},>5-10,>10-20,>20$ $30)$, and were the explanatory variables at individual level.

\section{Sample size calculation}

For $95 \%$ confidence interval and, significance level $\alpha=5 \%$, $\mathrm{P}=50 \%, \mathrm{Q}=50 \%$, allowable error $=11 \%$, required sample size was $317 . \mathrm{P}=$ percentage of germ cell tumor. In the pilot study done prior to the original study with 10 patients. $^{5}$

\section{Ethical committee approval}

Prior the study, ethical committee approval was taken from the institutional ethical committee, Manipal Teaching hospital, Pokhara, Nepal. The Research was conducted in accordance to latest version of the Declaration of Helsinki.

\section{Data management and statistical analysis}

The data collected was analyzed using Excel 2003, R 2.8.0 Statistical Package for the Social Sciences (SPSS) for Windows Version 16.0 (SPSS Inc; Chicago, IL, USA) and EPI Info 3.5.1 Windows Version. The $\mathrm{Z}$ test was used to observe the difference between different variables. $\mathrm{p}<0.05$ was considered as statistically significant. ${ }^{6}$

\section{RESULTS}

A total of 340 cases of ovarian tumors have been reported in the same period and among them, 150 cases (44\%) were of germ cell origin. The number and percentage of different types as well as $95 \%$ confidence interval of all benign and malignant germ cell tumors have been tabulated in Table 1. Benign germ cell tumors were 137 (40.3\%) of all ovarian tumors and $91.3 \%$ of germ cell tumors. Malignant germ cell tumors constituted $3.8 \%$ (n-13) of all ovarian tumors and $8.6 \%$ of germ cell tumors. Most common subtype in our series was mature cystic teratoma $(n=125)$. Among the malignant cases, the most common type was immature teratoma $(n=5)$. The age distribution and bilaterality of different types of benign and malignant germ cell tumors have been tabulated in Table 2. Age range in our series was from 8 to 82 years with a mean of 28 years. The commonest age group affected was 21-30 years followed by 31-40 years and 41-50 years. Most of the malignant cases (10/13, $76.9 \%$ ) were in women of less than 30 years. Out of all 150 cases 11 were bilateral. None of the malignant germ cell tumor was bilateral. Size of all different types of germ cell tumors including bilateral cases are shown in Table 3. The tumor size ranged from $3 \mathrm{~cm}$ to $27 \mathrm{~cm}$ with 95 cases $(63 \%)$ in the category $5-10 \mathrm{~cm}$ followed by $10-20 \mathrm{~cm}(\mathrm{n}=51$, $34 \%)$. Among the malignant cases majority $(11 / 13,84.6 \%)$ were more than $10 \mathrm{~cm}$ in size. Statistical analysis of age and size distribution of all the subtypes were carried out and are tabulated in Tables 4 and 5 respectively.

\section{DISCUSSION}

Germ cell tumors are a heterogeneous group, majority originating at different stages of development from germ cells. ${ }^{7}$ Some are composed of undifferentiated cells (dysgerminoma, embryonic carcinoma) while in others there is differentiation towards embryonic (teratoma)

Table 1: Frequency and percentage of different types of germ cell tumor

\begin{tabular}{llcl}
\hline \multicolumn{1}{c}{ GERM CELL TUMOR } & Percentage and 95\% CI among & $\begin{array}{c}\text { Percenntage and 95\% CI among all } \\
\text { Germ cell tumors }(\mathbf{n}=\mathbf{1 5 0})\end{array}$ & $40.3(35.08,45.51)$ \\
\hline BENIGN & 137 & $91.3(86.83,95.84)$ & $36.8(31.64,41.89)$ \\
Mature cystic Teratoma & 125 & $83(77.37,89.30)$ & $0.6(0,1.40)$ \\
\hline Struma ovarii & 2 & $1.3(0,3.17)$ & $1.4(0.19,2.75)$ \\
Mature teratoma with Serous cystadenoma & 5 & $3.3(0.46,6.21)$ & $0.9(0,1.88)$ \\
\hline Mature teratoma with Mucinous cystadenoma & 3 & $2(0,4.24)$ & $0.6(0,1.40)$ \\
\hline Mature teratoma with benign Brenner tumor & 2 & $1.3(0,3.17)$ & $3.8(1.79,5.86)$ \\
\hline MALIGNANT & 13 & $8.6(4.16,13.17)$ & $0.3(0,0.87)$ \\
\hline Mature teratoma with Mucinous borderline & 1 & $0.6(0,1.97)$ & $0.3(0,0.87)$ \\
\hline Mature teratoma with Sq Cell CA & 1 & $0.6(0,1.97)$ & $0.3(0,0.87)$ \\
\hline Mature teratoma with Sq Cell CA and Mucinus borderline & 1 & $0.6(0,1.97)$ & $0.3(0,0.87)$ \\
\hline Mature teratoma with undiff CA & 1 & $0.6(0,1.97)$ & $1.4(0.19,2.75)$ \\
\hline Immature teratoma & 5 & $3.3(0.46,6.21)$ & $0.9(0,1.40)$ \\
\hline Dysgerminoma & 2 & $1.3(0,3.17)$ & $0.3(0,0.87)$ \\
\hline Choriocarcinoma & 1 & $0.6(0,1.97)$ & $0.3(0,0.87)$ \\
\hline Yolk Sac Tumor & 1 & $0.6(0,1.97)$ & $44.1 \%$ \\
\hline TOTAL & 150 & $100 \%$ & \\
\hline
\end{tabular}


or extraembryonic (choriocarcinoma, yolk sac tumor) structures. $^{8}$ They account for nearly $30 \%$ of all ovarian tumors. ${ }^{7,9}$ In the current data, they constituted $44 \%$ of all ovarian tumors.

\section{Benign germ cell tumors}

Mature cystic teratoma is the most common ovarian neoplasm comprising $25 \%$ or more. ${ }^{9}$ In studies by Mondal SK et al and Jha $\mathrm{R}$ et al mature cystic teratoma comprised $68.9 \%$ and $95.6 \%$ of all germ cell tumors. ${ }^{13,14}$ In Western literature $95 \%$ of ovarian germ cell tumors are mature cystic teratoma. ${ }^{15,16}$ In our study, $125 / 150$ cases were mature cystic teratoma, comprising $83.3 \%$ of all germ cell tumors and $36.8 \%$ of all ovarian tumors.

Grossly it is mostly unilocular cyst filled with grumous sebaceous material and hair. Microscopy reveals mature adult type tissue derived from two or three embryonic layers, most commonly being ectoderm. Struma ovarii is the most common type of monodermal teratoma. ${ }^{7}$ However , only 2 cases out of 150 cases were reported as struma ovarii. There were 10 cases of composite tumors where mature teratoma was associated with serous cystadenoma ( $n=5)$, with mucinous cystadenoma $(n=3)$ and with benign Brenner tumor $(n=2)$.

Majority of mature cystic teratoma are known to occur in less than 50 years with the peak being between 20 and 29 years. $^{7,8}$ Similarly, in the present series majority $(n=110$; $88 \%$ ) were below 50 years and it was statistically significant with $\mathrm{p}$ value 0.001 . The peak for mature cystic teratoma was in the age group 21-30 comprising 54 cases (43.2\%). Benign teratomas are known to be bilateral in $10-15 \%$ cases. $^{8}$ In our series, $8 \%(n=13)$ benign teratomas where bilateral. Benign teratomas range in size from a few centimeter to large tumor with average being 7-8 cm. ${ }^{8}$ We reported cases with a range from $2 \mathrm{~cm}$ to $27 \mathrm{~cm}$. Majority were less than $10 \mathrm{~cm}$ with significant $\mathrm{p}$ value and most common group being $5-10 \mathrm{~cm}$. However though the average size of Struma ovarii is 5-10 $\mathrm{cm}$, the 2 cases we reported were of $8 \mathrm{~cm}$ and $15 \mathrm{~cm}$ in size.

\section{Malignant germ cell tumors}

Immature teratoma is one of the most common malignant germ cell tumors representing $20-30 \%$ of these tumors at major cancer centers. ${ }^{17,18}$ Only 3\% of ovarian teratomas are immature. ${ }^{15,16}$ They occur in young age group and are typically unilateral with average size of $18 \mathrm{~cm} .{ }^{8}$ In our study, 5 cases (3.4\%) were immature teratoma. Age and size distribution were statistically significant in the present study, as all were below 30 years of age and majority were more than $10 \mathrm{~cm}$. One case had size of less than $10 \mathrm{~cm}$ while rest 4 cases were between 10 and $20 \mathrm{~cm}$. A mixture of mature and immature tissue; mostly in the form of neuroectodermal rosettes and tubules were seen. Histologically, they can be graded into grade 1, 2 and 3 according to extent of neuroectodermal component. ${ }^{7,8}$ We had 2 cases of grade 1 and 3 cases of grade 2 tumor.

Approximately $1-3 \%$ of benign mature teratoma may undergo malignant transformation. ${ }^{8}$ In a study of 87 ovarian teratomas, Papadias et al reported 5\% cases with malignant changes. ${ }^{19}$ Secondary malignancies are typically

Table 2: Age distribution and bilaterality of different types of germ cell tumor

\begin{tabular}{|c|c|c|c|c|c|c|c|c|c|c|c|}
\hline \multirow[t]{2}{*}{ GERM CELL } & & \multicolumn{8}{|c|}{ AGE } & \multicolumn{2}{|c|}{ SIDE } \\
\hline & & $<10$ & $11-20$ & $21-30$ & $31-40$ & $41-50$ & $51-60$ & $61-70$ & $>70$ & Uni & Bilatearal \\
\hline \multicolumn{12}{|l|}{ BENIGN } \\
\hline Mature cystic Teratoma & 125 & 1 & 5 & 54 & 29 & 21 & 10 & 4 & 1 & 114 & 11 \\
\hline Struma ovarii & 2 & & & & 1 & 1 & & & & 2 & \\
\hline Mature teratoma with Serous cystadenoma & 5 & & & 3 & 1 & 1 & & & & 4 & 1 \\
\hline Mature teratoma with Mucinous cystadenoma & 3 & & & 2 & 1 & & & & & 3 & \\
\hline Mature teratoma with benign Brenner tumor & 2 & & & & & 1 & 1 & & & & 1 \\
\hline \multicolumn{12}{|l|}{ MALIGNANT } \\
\hline Mature teratoma with Mucinous borderline & 1 & & & & 1 & & & & & 1 & \\
\hline Mature teratoma with Sq Cell CA & 1 & & & & & 1 & & & & 1 & \\
\hline $\begin{array}{l}\text { Mature teratoma with Sq Cell CA and Mucinus } \\
\text { borderline }\end{array}$ & 1 & & & & & & 1 & & & 1 & \\
\hline Mature teratoma with undiff $\mathrm{CA}$ & 1 & & & & & 1 & & & & 1 & \\
\hline Immature teratoma & 5 & & 2 & 3 & & & & & & 5 & \\
\hline Dysgerminoma & 2 & & & 1 & & & 1 & & & 2 & \\
\hline Choriocarcinoma & 1 & 1 & & & & & & & & 1 & \\
\hline Yolk Sac Tumor & 1 & & 1 & & & & & & & 1 & \\
\hline TOTAL & 150 & 2 & 8 & 63 & 33 & 26 & 13 & 4 & 1 & 134 & 13 \\
\hline
\end{tabular}


Table 3: Size distribution of different types of germ cell tumor

\begin{tabular}{|c|c|c|c|c|}
\hline \multirow{2}{*}{$\begin{array}{l}\text { GERM CELL TUMORS } \\
\text { ( including bilateral cases ) }\end{array}$} & \multicolumn{4}{|c|}{ SIZE in $\mathrm{cm}$} \\
\hline & Upto 5 & $>5-10$ & $>10-20$ & $>20-30$ \\
\hline \multicolumn{5}{|l|}{ BENIGN } \\
\hline Mature cystic Teratoma & 10 & 88 & 36 & 2 \\
\hline \multicolumn{5}{|l|}{ Mature teratoma } \\
\hline with Serous cystadenoma & 2 & 3 & 1 & \\
\hline with Mucinous cystadenoma & & & 3 & \\
\hline with benign Brenner tumor & 2 & 1 & & \\
\hline Struma ovarii & & 1 & 1 & \\
\hline \multicolumn{5}{|l|}{ MALIGNANT } \\
\hline \multicolumn{5}{|l|}{ Mature teratoma } \\
\hline with Mucinous Borderline & & & & 1 \\
\hline with SCC* & & & 1 & \\
\hline $\begin{array}{l}\text { with SCC and Mucinus } \\
\text { borderline }\end{array}$ & & & 1 & \\
\hline with undifferentiated $\mathrm{Ca}^{* *}$ & & & 1 & \\
\hline Immature teratoma & & 1 & 4 & \\
\hline Dysgerminoma & & & 2 & \\
\hline Choriocarcinoma & & 1 & & \\
\hline Yolk Sac Tumor & & & 1 & \\
\hline TOTAL & 14 & 95 & 51 & 3 \\
\hline
\end{tabular}

$\dagger$ Statistical significance $(\mathbf{p}<\mathbf{0 . 0 5}),{ }^{*}$ - Squamous Cell Carcinoma,

** - Carcinoma

seen in postmenopausal women and $85 \%$ are squamous cell carcinoma. ${ }^{7}$ We had only 4 cases of teratomas with secondary malignancy; 2 with squamous cell carcinoma and 1 with undifferentiated carcinoma and 1 with mucinous borderline areas.

Dysgerminoma is a common malignant germ cell tumor of the ovary.10-12 Eighty percent of tumors develop in women younger than 30 yrs of age with mean age 21 years. They are extremely rare above 50 years. 9 Out of 2 cases in our study, 1 case was of 55 years. Microscopically predominantly diffuse pattern of primitive monotonous germ cells with PAS positive cytoplasm are seen (fig.1). The stroma is usually thin with varying number of lymphocytes.

Pure primary ovarian choriocarcinoma of germ cell origin is extremely rare and comprise less than $1 \%$ of all ovarian germ cell neoplasms. ${ }^{7,8}$ We reported only one case in the current study. Diligent search for other germ cell component should be carried out as choriocarcinoma is seen mostly as a component of a mixed germ cell tumor. Grossly they are typically hemorrhagic and microscopy is similar to its endometrial counterpart.

Yolk sac tumors are morphologically heterogenous and may show many epithelial patterns. The only case we had was of 16 years of age and showed classical reticular pattern and Schiller Duval bodies (fig 2.).

Mixed germ cell tumors are composed of at least two different germ cell component, the most common combination being dysgerminoma and yolk sac tumor. ${ }^{3}$ All the components with their approximate proportion should be noted in the diagnosis. ${ }^{7}$ Therapeutic regimen is based on the most malignant element. ${ }^{20}$ We did not encounter any case under this category.

Table 4: Statistical analysis and significance of age distribution of different types of germ cell tumor

\begin{tabular}{|c|c|c|c|c|c|c|c|}
\hline \multirow{3}{*}{$\begin{array}{l}\text { BENIGN } \\
\text { Mature cystic Teratoma }\end{array}$} & \multicolumn{7}{|c|}{ Age } \\
\hline & \multirow{2}{*}{$\begin{array}{c}<50 \mathrm{n}(\%) \\
110(88)\end{array}$} & \multirow{2}{*}{$\frac{<50 \mathrm{n}(\%)}{15(12)}$} & \multirow{2}{*}{$\frac{\text { Total }}{125}$} & \multicolumn{2}{|c|}{$\begin{array}{l}95 \% \text { CI for } \\
\text { Difference }\end{array}$} & \multirow{2}{*}{$\begin{array}{r}\text { Z-value } \\
18.49\end{array}$} & \multirow{2}{*}{$\frac{\text { P-value }}{0.0001}$} \\
\hline & & & & 67.9435 & 84.0565 & & \\
\hline Struma ovarii & $2(100)$ & 0 & 2 & - & - & - & - \\
\hline Mature teratoma with Serous cystadenoma & $5(100)$ & 0 & 5 & - & - & - & - \\
\hline Mature teratoma with Mucinous cystadenoma & $3(100)$ & 0 & 3 & - & - & - & - \\
\hline Mature teratoma with benign Brenner tumor & $1(50)$ & $1(50)$ & 2 & - & - & - & - \\
\hline \multicolumn{8}{|l|}{ MALIGNANT } \\
\hline With Mucinous Borderlie & $1(100)$ & 0 & 1 & - & - & - & - \\
\hline Mature teratoma with Sq Cell CA & $1(100)$ & 0 & 1 & - & - & - & - \\
\hline Mature teratoma with Sq Cell CA and Mucinus borderline & 0 & $1(100)$ & 1 & - & - & - & - \\
\hline Mature teratoma with undiff $\mathrm{CA}$ & $1(100)$ & 0 & 1 & - & - & - & - \\
\hline Immature teratoma & $5(100)$ & 0 & 5 & - & - & - & - \\
\hline Dysgerminoma & $1(50)$ & $1(50)$ & 2 & - & - & - & - \\
\hline Choriocarcinoma & $1(100)$ & 0 & 1 & - & - & - & - \\
\hline Yolk Sac Tumor & $1(100)$ & 0 & 1 & - & - & - & - \\
\hline Total & $132(88)$ & $18(12)$ & & & & & \\
\hline
\end{tabular}

$\dagger$ Statistical significance $(\mathbf{p}<0.05)$ 
Table 5: Statistical analysis and significance of age distribution of different types of germ cell tumor

\begin{tabular}{|c|c|c|c|c|c|c|c|}
\hline & \multicolumn{7}{|c|}{ Age } \\
\hline & $<50 \mathrm{n}(\%)$ & $<50 \mathrm{n}(\%)$ & Total & \multicolumn{2}{|c|}{$\begin{array}{l}95 \% \text { CI for } \\
\text { Difference }\end{array}$} & Z-value & P-value \\
\hline \multicolumn{5}{|l|}{ BENIGN } & & & \\
\hline Mature cystic Teratoma & $98(72.05)$ & $38(27.94)$ & 136 & 33.45 & 54.78 & 8.11 & $0.0001 \dagger$ \\
\hline Struma ovarii & $1(50)$ & $1(50)$ & 2 & - & - & 0 & 1 \\
\hline Mature teratoma with Serous cystadenoma & $5(83.33)$ & $1(16.67)$ & 6 & 24.49 & 100 & 3.10 & $0.001946 \dagger$ \\
\hline Mature teratoma with Mucinous cystadenoma & 0 & $3(100)$ & 3 & - & - & - & - \\
\hline Mature teratoma with benign Brenner tumor & $3(100)$ & 0 & 3 & - & - & - & - \\
\hline \multicolumn{8}{|l|}{ MALIGNANT } \\
\hline With Mucinous Borderlie & 0 & $1(100)$ & 1 & & & & \\
\hline Mature teratoma with Sq Cell CA & 0 & $1(100)$ & 1 & & & & \\
\hline Mature teratoma with Sq Cell CA and Mucinus borderline & 0 & $1(100)$ & 1 & & & & \\
\hline Mature teratoma with undiff CA & 0 & $1(100)$ & 1 & & & & \\
\hline Immature teratoma & $1(20)$ & $4(80)$ & 5 & - & - & 2.37 & $0.017706 \dagger$ \\
\hline Dysgerminoma & 0 & $2(100)$ & 2 & & & & \\
\hline Choriocarcinoma & $1(100)$ & 0 & 1 & & & & \\
\hline Yolk Sac Tumor & 0 & $1(100)$ & 1 & & & & \\
\hline Total & 109 & 54 & & & & & \\
\hline
\end{tabular}

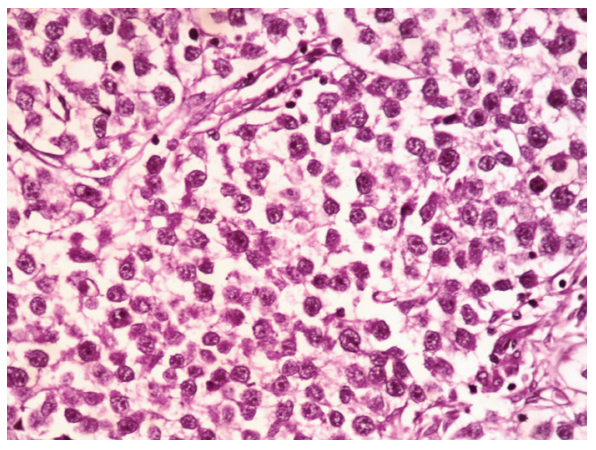

Figure 1: Dysgerminoma showing tumor cells in diffuse sheets separated by thin $f$ brous septae lymphocytes and capillaries (HE stain, X400)

\section{CONCLUSION}

Among germ cell tumors of ovary, mature cystic teratoma is the most common tumor and malignant subtypes are uncommon. Malignant tumors tend to occur in younger age group.

\section{REFERENCES}

1. Lee KR, Russel P, Tavassoli FA et al. Surface epithelial stromal tumours. In: Travassoli FA, Devilee P eds. Pathology and genetics of tumours of the breast and female genital organs. IARC Press, Lyon ;2003. pp117-45.

2. Christopher P. Crum. The female genital system. In : Kumar V, Abbas AK, Fausto N, editor. Robbins and Cotran, Pathologic Basis of Disease. 7th ed. Elsevier;2004. pp1092-114.

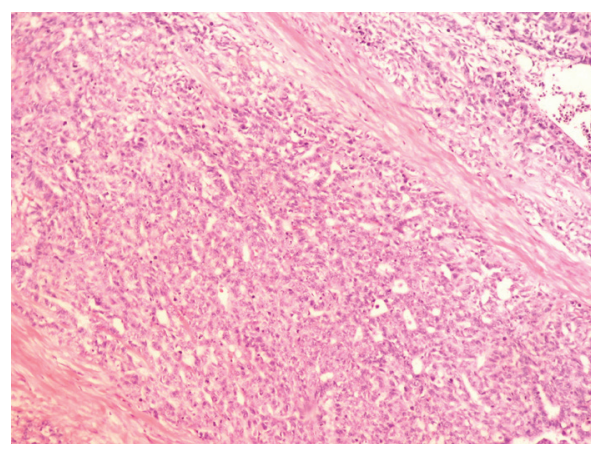

Figure 2: Yolk sac tumor showing reticular pattern and Schiller-Duval bodies (HE stain, X100)

3. Rosai J. Ovary. In: Ackerman's Surgical Pathology vol 2. 9th ed. Missouri: Mosby Elsevier; 1997. pp1649-1736

4. Scully RE, Clement PB, Young RH. Ovarian surface epithelialstromal tumors. In: Carter D, Greenson JK, Oberman HA, Reuter V, Stoler MH, editors. Sternberg's Diagnostic Surgical pathology. 4th ed. Lippincott Williams and wilkins: Philadelphia; 2004.pp2543-73.

5. Sathian B, Sreedharan J, Baboo NS, Sharan K, Abhilash ES, Rajesh E. Relevance of Sample Size Determination in Medical Research. Nepal J Epidemiol 2010;1:4-10.

6. Sathian B. Methodological Rigors in Medical Journals from Developing Countries: An Appraisal of the Scenario in Asia. Nepal J Epidemiol 2011;1:141-43.

7. Nogales F, Talerman A, Kubik -Huch RA, Travassoli FA, 
Devouassoux- Shisheboran M. germ cell tumours. . In: Travassoli FA, Devilee P, editors. Pathology and genetics of tumours of the breast and female genital organs. IARC Press, Lyon ;2003.pp163-75.

8. Zaloudek C. Tumors of the ovary. In:Fletcher CDM, editor. Diagnostic histopathology of tumors. 2nd ed. Churchill Livingstone, Philadelphia; 2005. pp567-641.

9. Young RH, Clement PB, Scully RE. Sex cord stromal, steroid cell, and germ cell tumors of the ovary. In: Carter D, Greenson JK, Oberman HA, Reuter V, Stoler MH, editors. Sternberg's Diagnostic Surgical pathology. 4th ed. Lippincott Williams and wilkins: Philadelphia;2004.pp2579-616.

10. Katsube Y, Berg JW, Silverberg SG. Epidemiologic pathology of ovarian tumors: a histopathologic review of primary ovarian neoplasms diagnosed in the Denver Standard Metropolitan Statistical Area, 1July -31 December 1969 and 1 July -31December 1979. Int J Gynecol Pathol 1982;1:3-16

11. Koonnings PP, Campbell K, Mishell DR Jr. Relative frequency of primary ovarian neoplasms : a 10 year review. Obstet Gynecol 1989;74:921-26.

12. Russel P, Painter DM. The pathological assesement of ovarian neoplasms. V. the germ cell tumors. Pathology 1982;14:47-72

13. Mondal SK, Banyopadhyay R, Nag DR, Roychowdhury S, Mondal PK, Sinha SK. Histologic pattern, bilaterality and clinical evaluation of 957 ovarian neoplasms: A 10-year study in a tertiary hospital of eastern India. J Can Res Ther 2011;7:433-7
14. Jha R, Karki S. Histological pattern of ovarian tumors and their age distribution. Nepal Med Coll J 2008;10:81-5.

15. Scully Robert E, Young Robert H, Clement Phillip B. Atlas of Tumor Pathology. Tumors of the ovary, maldeveloped gonads, fallopian tube and broad ligament. 3rd series, Fascicle 23. Armed Force Institute of Pathology, 1999.

16. Tavassoli FA, Devilee P. WHO Classification of Tumors.Pathology and Genetics, Tumors of Breast and Female Genital Organs. IARC Press: Lyon 2003.

17. Gershenson DM, Copeland LJ, Kavanagh JJ. Treatment of malignant nondysgerminomatous germ cell tumors of the ovary with vincristine, dactinomycin and cyclophosphamide. Cancer 1985;56:2756-61.

18. Bonazzi C, Peccatori F, Colombo N. Pure ovarian immature teratoma, a unique and curable disease: 10 years experience of 32 prospectively treated patients. Obstet Gynecol 1994; 84:598-604.

19. Papadias K, Kairi-Vassilatou E, Kontogiani-Katsaros K, Argeitis J, Kondis-Pafitis A, Greatsas G. Teratomas of the ovary: A clinicopathological evaluation of 87 patients from one institution during a 10-year period. Eur J Gynaecol Oncol 2005;26:446-8.

20. Talerman A. Germ cell tumors of the ovary. In: Blaustein's pathology of the Female Genital Tract, Kurman RJ, Blaustein A editors 5 ed Springer Verlag New York 2002 967-1034 